\title{
Managing public health expectations: the micro community model of bio-preparedness
}

\author{
A. Heffron Casserleigh \& J. Broder \\ Florida State University, USA
}

\begin{abstract}
The cycle of bio-preparedness is formulaic based on threat assessments, public impact, and resources. Since 2007 the resource allocation for bio-preparedness in the United States has been reduced and has shifted focus based on a changing perception of threat and public vulnerability. These resource reductions have mandated a retraction of government involvement in care and distribution of goods in a bio event. Bio preparedness programs now focus almost exclusively on micro community education including self-care and provisioning during an event.

The United States resource commitment to bio-preparedness planning was extensive after the 2001 Anthrax attacks, which, seen in the light of the 9/11 attacks, created a perception of biological vulnerability. This increased perception of threat and possible public impact led to a commitment of vast resources totaling several trillion US dollars between 2001 and 2006. These resources went primarily to preparedness and monitoring activities, which included a series of biological event exercises named "Bioshield" that revealed some startling shortfalls.

This paper will examine the after action reports of three state wide Bioshield exercises; both the outcomes and their recommendations for bio planning improvements. These results will be compared to the implementation events that took place as a result of the 2009 H1N1 "Swine Flu" response, and the subsequent recommendations and refining of bio-preparedness planning. This paper will also include current bio-planning efforts which implement the exercise and post Swine Flu event recommendations of micro-community selfreliance. The intended definition of a micro community for purposes of paper is
\end{abstract}


a grouping of citizens which share a religious, ethnic, or cultural commonality as a basis for communal organization, preparedness, and resilience.

Keywords: bio-preparedness, Bioshield exercise, micro-community readiness, public health, health policy, Strategic National Stockpile (SNS), vendor managed inventory (VMI).

\section{Introduction}

Focusing events cause people to shift their attention to a singular problem in an attempt to understand and address a unique situation. This focused attention includes policy makers, elected officials and in the case of disaster, also emergency managers. These sudden and vivid events simulate a greater interest in a problem and often induce a policy change (Cobb and Elder [1], Baumgartner and Jones [2]). Because focusing events are significant in history there is often a rally to change either the response to the event or to mitigate similar events from occurring. This influence can come from the people in the form of mass protests and media attention, and usually call for policy makers to act (Birkland [3]). The actions undertaken by politicians and policy makers usually include changes that require budgetary support, and bio-preparedness is no exception.

\section{Bio-preparedness budgets}

The contemporary history of bio-preparedness in the United States is benchmarked by several important initiatives. The first initiative is the 1999 creation of the Strategic National Stockpile (SNS), a national repository of pharmaceuticals and critical equipment staged throughout the country and available to any city or state within 12 hours or request. Funded by the US Congress in 1999 the SNS includes the Vendor Managed Inventory (VMI) program of specialized supplies that are also available to any US community within 24 hours. The specialization of the VMI allows for the deployment of specific drugs, often directly from the manufacturer. The VMI response to the 2001 Anthrax attacks included Ciprofloxacin hydrochloride (CIPRO) or ciprofloxacin, a synthetic broad spectrum antimicrobial agent for oral administration, was used both for treatment to those with symptoms and those suspected of exposure (Prior [4]).

Funding for the SNS is a reflection of the overall commitment to the biopreparedness program. During its creation the SNS had a price tag of only $\$ 50$ million for fiscal years 1999-2002 (Prior [4]). Following the Anthrax attacks of fall 2001 , the funding grew more than ten-fold, reflecting the national priority of bio-preparedness.

The first bio-preparedness focusing event was the 2001 Anthrax attacks, especially potent after the 9/11 terror attacks of the same year. Known as "Amerithrax", the attack involved weaponized Anthrax delivered via the US Postal Service to several US Senators, ultimately killing 5 people and infecting 17 others (Sarasin [5]). 
The Amerithrax attack brought to light vulnerabilities in identifying and treating unique biological weapons. The publics' fears were exacerbated by other recent attacks and the perception of vulnerability was high. After the Amerithrax attack US Congress made bio-preparedness a priority and passed a budget of over $\$ 4$ billion for FY 2002, as shown in Figure 1. The majority of the funding went to the federal Health and Human Service agency, that subsequently passed down to states and a major metropolitan city through preparedness grants (Franco [6]).

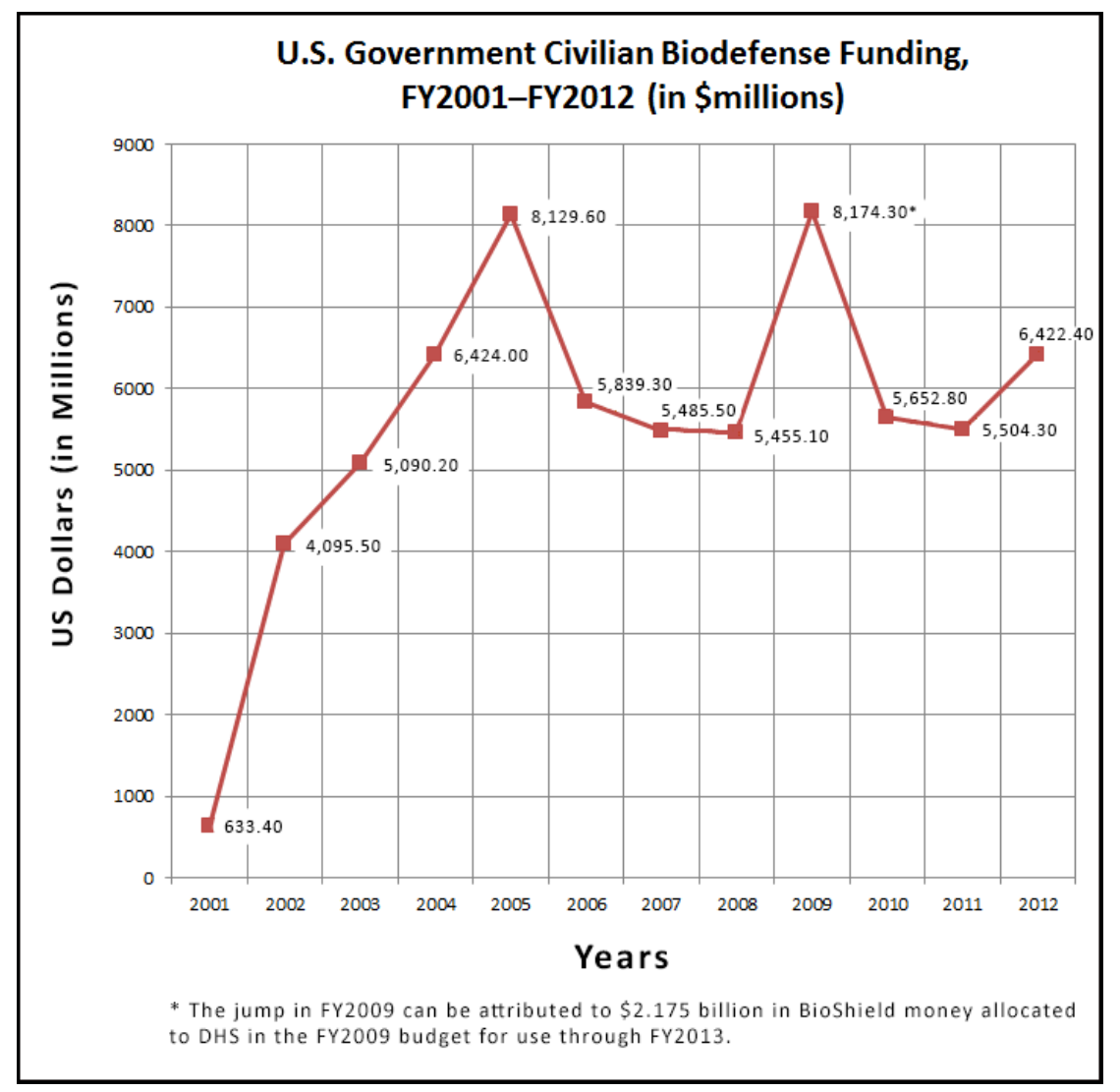

Figure 1: $\quad$ U.S. Government Civilian Biodefense Funding, FY2001-FY2012.

What is most notable about the US bio-preparedness budget is the dramatic decline it makes in the 2005-2006 fiscal year. Specifically,

"Federal funds for state and local preparedness declined by 38 percent from fiscal year (FY) 2005 to 2012 (adjusted for inflation) - and additional cuts are expected under budget sequestration. From FY2010 
to FY2012, there is a $\$ 72$ million reduction to Public Health and Emergency Preparedness grants from state, local, territorial, and tribal funds, a \$22 million cut to the Academic Centers for Public Health Preparedness and \$5 million from the Advanced Practice Centers" (Trust for America's Health [7]).

This dramatic decrease in bio-preparedness support can most likely be attributed to several factors, not the least of which was a global economic downturn. The combined cost from FY2001-2006 was \$30.2 billion (Franco [6]) and with no outbreaks or biological attacks during this period it is understandable why the bio-preparedness budget was reduced.

\section{State level bio-preparedness}

The primary purpose of bio-preparedness money was to strengthen response and distribution capabilities at the state level. This included the distribution of the SNS in a timely and efficient manner once it was received by the states. The bulk of the preparedness money went towards planning and exercising distribution capabilities, specifically the use of Point of Distribution (POD) centres.

Most industrialized countries are required by legislation to conduct disaster exercises that include natural and technological threats (Peterson and Perry [8]). Annual exercises ensure that "potential shortcomings in the plan and training process are identified" (Peterson and Perry [8]). Therefore, these exercises are seen as an important aspect in the process of emergency management. Five core benefits attributed to disaster exercises include:

1. Permitting "inferential testing of the adequacy of a disaster plan";

2. Allowing inferential testing of the "adequacy of training of personnel";

3. Enhancing the visibility of the agencies participating in the exercise with those in the community, and "similarly reassuring the public that emergency authorities are aware of dangers and prepared to take measures to reduce negative impacts";

4. Providing a "hands-on" check of communication equipment, systems, and other materials; and

5. Testing the "viability of the emergency response network relative to the threat exercised" (Peterson and Perry [8]).

Of the various exercises conducted by emergency managers for disaster planning, three of the most commonly used include: tabletop, functional, and full scale (Peterson and Perry [8]). Functional and full scale exercises are considered operations based exercises and are the most accurate for testing a community's response capabilities. The third type of exercise is the tabletop exercise which is 
used to test plans and operations through discussion before conducting a full scale exercise. All three of these exercises involve simulated, hypothetical manmade or natural disasters in which the participants are asked to respond to the event's demands (Moyer [9]; Peterson and Perry [8]). They are designed to "test and evaluate proposed plans and procedures and resolve questions of coordination and responsibility before implementation of a plan" (Watkins [10]). While familiarizing the participants with the administration of response procedures, these exercises also provide insight for the need of cooperation, resources, and communication during a disaster or emergency situation (Watkins [10]). Full scale exercises are particularly beneficial when trying to implement roles and responsibilities among participating organizations and assess plans, policies, and procedures.

Overall, exercises aid and enhance the participants' "perceptions of response network effectiveness", which is primarily focused on collateral support (Peterson and Perry [8]). These networks between first responders are important because of the decisions, actions, and strategies that will "form the core of any response operation" (Richter, et al. [11]). Peterson and Perry's [8] study concluded that exercises have the capability to alter participant perceptions of not only response network effectiveness, but also teamwork, training and equipment adequacy, and job risk.

\section{The "Bioshield" initiative}

The requirements of bio-preparedness are a "when" not "if" scenario. 15-20 previously unknown diseases have been discovered in the past few decades including HIV/AIDS, Ebola, hepatitis C, Lyme disease, Hantavirus pulmonary syndrome, and Severe Acute Respiratory Syndrome (Graham [12]). New strains of influenza and other newly emerging diseases are likely to spread even more broadly and quickly due to the mobility of the world's population. With influenza as the world's greatest biological challenge and a widely quoted awareness massage reminds us, "The influenza pandemic of 1918-1919 killed more people than World War I (WWI), at somewhere between 20 and 40 million people" (Barry [13]). The Spanish Influenza has been on record as the most devastating epidemic in recorded world history, with far great deaths than in four-years of the Black Death Bubonic Plague from 1347 to 1351.

There are a variety of bio-scenarios, as seen in Table 1, that would warrant individual preparedness over national response. At the small scale contagious event the individual or micro community would self-care, and if necessary lean on the medical infrastructure. At the large scale contagious level the professional medical community would be overwhelmed sheltering in place and individual self-care would be the message (Graham [12]) (Trust for America's Health [7])

From 2002-2006 the Florida Department of Heath undertook a series of "Bioshield" exercises to simulate a variety of bio threats that could occur in the 
state. As with most exercises, the primary areas of weakness included "communication". Other results indicate the inability to distribute and track the distribution of the SNS pharmaceuticals (Florida Department of Health [14]). Specifically, the Bioshield Exercise After Action Report (2006) noted an inability to measure the State's ability to process requests of specific materials

Table 1: $\quad$ From Bio-Preparedness report card (Graham [12]).

\begin{tabular}{|c|c|}
\hline LEVEL & BIOLOGICAL EVENT \\
\hline SMALL-SCALE NON-CONTAGIOUS & $\begin{array}{l}\cdot \text { LIMITED EXPOSURE TO PATHOGEN } \\
\cdot \text { NO ADDITIONAL EXPOSURES } \\
\cdot \text { SMALL NUMBERS OF ILLNESSES } \\
\text { AND/OR DEATHS } \\
\text { • POTENTIAL FOR MEASURABLE } \\
\text { PSYCHOLOGICAL AND SOCIO- } \\
\text { ECONOMIC IMPACT }\end{array}$ \\
\hline SMALL-SCALE CONTAGIOUS & $\begin{array}{l}\cdot \text { - LIMITED INITIAL EXPOSURE TO } \\
\text { PATHOGEN } \\
\cdot \text { SMALL NUMBERS OF ILLNESSES } \\
\text { AND/OR DEATHS } \\
\cdot \text { PERSON-TO-PERSON TRANSMISSION } \\
\text { WITH CONTAGION POTENTIAL } \\
\text { • POTENTIAL FOR MEASURABLE } \\
\text { PSYCHOLOGICAL AND SOCIO- } \\
\text { ECONOMIC IMPACT }\end{array}$ \\
\hline LARGE-SCALE NON-CONTAGIOUS & $\begin{array}{l}\cdot \text { EXPOSURE IN ONE OR MORE CITIES } \\
\text { • ADDITIONAL EXPOSURES POSSIBLE } \\
\text { OVER TIME } \\
\text { • EPIDEMIC NUMBERS OF ILLNESSES } \\
\text { AND/OR DEATHS } \\
\text { • SIGNIFICANT PSYCHOLOGICAL AND } \\
\text { SOCIO-ECONOMIC IMPACT: CIVIL } \\
\text { UNREST }\end{array}$ \\
\hline LARGE-SCALE CONTAGIOUS & $\begin{array}{l}\text { • EXPOSURE IN ONE OR MORE CITIES } \\
\text { • ADDITIONAL EXPOSURES OVER TIME } \\
\text { • EPIDEMIC NUMBERS OF ILLNESSES } \\
\text { AND/OR DEATHS WITH CONTAGION } \\
\text { POTENTIAL } \\
\text { • SIGNIFICANT PSYCHOLOGICAL AND } \\
\text { SOCIO-ECONOMIC IMPACT: CIVIL } \\
\text { UNREST }\end{array}$ \\
\hline
\end{tabular}


Table 1: $\quad$ Continued.

\begin{tabular}{|c|c|}
\hline LEVEL & BIOLOGICAL EVENT \\
\hline LARGE-SCALE DRUG RESISTANT & $\begin{array}{l}\text { - EXPOSURE IN ONE OR MORE CITIES } \\
\text { • ADDITIONAL EXPOSURES OVER TIME } \\
\text { • POTENTIALLY UNCONTROLLABLE } \\
\text { NUMBER OF ILLNESSES AND/OR } \\
\text { DEATHS } \\
\text { • MEDICAL COUNTERMEASURES } \\
\text { UNAVAILABLE OR INEFFECTIVE } \\
\text { • CIVIL AND POLITICAL UNREST IN THE } \\
\text { AFFECTED REGION; GLOBAL } \\
\text { ECONOMIC IMPACT }\end{array}$ \\
\hline GLOBAL CRISIS CONTAGIOUS & $\begin{array}{l}\text { • NUMEROUS EXPOSURES IN MULTIPLE } \\
\text { LOCATIONS OF HIGHLY CONTAGIOUS, } \\
\text { NOVEL PATHOGEN(S) } \\
\text { • MEDICAL COUNTERMEASURES } \\
\text { UNAVAILABLE } \\
\text { • GLOBAL OUTBREAK WITH POTENTIAL } \\
\text { FOR MILLIONS OF ILLNESSES AND/ OR } \\
\text { DEATHS } \\
\text { • BREAKDOWN OF POLITICAL } \\
\text { INSTITUTIONS; GLOBAL ECONOMIC } \\
\text { DISRUPTION }\end{array}$ \\
\hline
\end{tabular}

for distribution in a bioterrorism event, and noted, "The final order that was entered into Tracker (a state wide system used by Florida to monitor resources and requests during emergencies) exceeded the inventory on hand" (Florida Department of Health [14]). The State also self-reported their inability to track and account for the delivery of SNS assets sent to Points of Dispensing (PODs). Staffing was also a concern and because this was the fourth year the Bioshield exercise had been undertaken it is significant to note that in 2006 Florida reported, "Some confusion as to who was assigned primary and alternate responsibilities" (Florida Department of Health [14]).

In 2005 Florida exercised its Point of Distribution (POD) plan for the SNS in Orange Country Florida, home of Disney World. The exercise was deemed a "success" but there were noteworthy results, including the amount of time and resources it would need to operate a POD in a real bio event. The POD Exercise After Action Report indicated that a single POD, staffed with 86 people per shift, could handle 420 people (clients) per hour (Florida Department of Health [15]). The exercise was unable to get a significant number of volunteers so this load of clients was extrapolated as a best case scenario. Given this assumption of throughput, and the population of Orange County at 1.169 million people, it would take 116 days of POD operations if they were open in 24 hour shifts. The 
exercise did not take into account other acknowledged influencing variables such as reduced staffing due to the bio event, the need for multiple shifts if operating in a 24 hour capacity, and the need for a system of separating the symptomatic clients during POD operations (Florida Department of Health [15]). Other challenges identified by the Florida Department of Health include language barriers between residents or tourists and health personnel, and a large number of undocumented workers within the state, which would inflate the number of the population.

\section{Micro community bio-preparedness}

Epidemiologists, disaster planners, and virologists agree that influenza pandemics have happened in the past and will happen in the future (Diprose [16]). The philosophy of prudence being mobilized in response to the threat of pandemic influenza is illustrative of the intensification of public health practices that distinguish individual preparedness from the national (Sassen in Diprose [16]). The results of the Florida Bioshield exercises reveal a weakness in the government's ability to effectively distribute pharmaceuticals to a single county, let alone a state of 19 million. It has also become a recognized challenge of all levels of government that beyond the distribution of pharmaceuticals to the populous is the quantity of pharmaceuticals that would have to be produced to meet the needs of a nation of 313 million. In the "Bio-response Report Card" (2011) published by a bi-partisan committee chaired by Senator Bob Graham states, "The nation does not yet have adequate bio-response capability to meet fundamental expectations during a large-scale biological event" (Graham [12]).

Understanding the limitations of government creates a paradigm shift in perceptions and the ability to meet the health and security of individuals in the state. Emerging and dynamic risks change the definitions of 'precaution' (Ewald [17]), 'preparedness' or 'pre-emption' (Derrida [18]). By 2007 the limitations of the state in response to bio-preparedness required policy makers to rethink the individual approach. Combined with a demand to curtail spending, resulting in a reduction of $\$ 3$ billion between FY2006 to FY 2007, this new approach revealed the individual or micro community bio-preparedness campaign. Individual or micro community bio-preparedness employs the "paradigm of prudence" model (Samimian-Darash [19]) and urges societies and individuals to be in a constant state of readiness about possible high-consequence threats. Whether pertaining to public health or bio-preparedness the paradigm urges that individuals be in a constant state of readiness about possible high-consequence threats or proactive in preparing for the arrival of disasters (Diprose [16]).

The paradigm of prudence and individual preparedness policy initiative in bio-preparedness has led to specific campaigns that "mobilize whole of the nation response planning" (Graham [12]). These whole nation responses include messages of individual levels of care in the event of an outbreak. These specific campaigns of awareness included open messages of state limitations combined 
with public awareness campaigns of individual preparedness. The official government message from both the Federal Emergency Management Agency (FEMA) and the Centers for Disease Control and Prevention (CDC) include the expectation that individuals "Have any non-prescription drugs and other health supplies on hand, including pain relievers, stomach remedies, cough and cold medicines, fluids with electrolytes, and vitamins" (FEMA [20]). The same public messaging also includes a recommendation that individuals, "get involved in your community as it works to prepare for an influenza pandemic (FEMA [20]).

\section{Conclusion}

There has been a measurable shift in public awareness of bio-preparedness and prevention in the past decade. The awareness campaigns of sneezing into your elbow, and intense hand washing have changed cultural norms and expectations. The cultural shift can be linked to the paradigm of prudence initiative that emerged as part of changing policy and resources. These policy shifts are related both to limitations of resources, including budgetary restrictions, and the need for improved plans as a result of intense state disaster exercises.

The focus on individual and micro-community preparedness, and the selfexpressed limitations of government, has created a public partnership between the state and the individual. This partnership is based on honest expectations and limitations resulting in a new level of responsibility and awareness. In fostering this partnership, a higher awareness of personal preparedness for biological events can be accomplished through continued state and federal funding for education and awareness of not just communities, but also the nation as a whole.

\section{References}

[1] Cobb, R. and Elder, C. (1983). Participation in American Politics : the Dynamics of Agenda-Building. Baltimore: Johns Hopkins University Press.

[2] Baumgartner, F. and Bryan D. J. (1993). Agendas and Instability in American Politics. Chicago: University of Chicago Press.

[3] Birkland, T. (1997). After Disaster: Agenda Setting, Public Policy and Focusing Events. Washington: Georgetown University Press.

[4] Prior, Stephen D. (2004). Who You Gonna Call? Responding to a Medical Emergency with the Strategic National Stockpile. Retrieved March 30, 2013 from: http://www.ndu.edu/CTNSP/docUploaded/DTP3\%20SNS.pdf

[5] Sarasin, P. (2006). Anthrax: Bioterror As Fact And Fantasy. Cambridge: Harvard University Press.

[6] Franco, C. a. (2011). Federal Agency Biodefense Funding FY2001FY2012. (Ann Liebert, Ed.) Retrieved April 5, 2013, from http://www.upmc-biosecurity.org/: $\quad$ http://www.upmc-biosecurity.org /website/resources/publications/2011/2011-06-07-biodeffunds.html\#fig2 
[7] Trust for America's Health. (2011). Protecting the Public's Health from Diseases, Disasters, and Bioterrorism. Washington: Robert Wood Johnson Foundation.

[8] Peterson, D. M. and Perry, R. W. (1999). The impacts of disaster exercises on participants. Disaster Prevention and Management, 8(4), 241-254.

[9] Moyer, J. (2005). Tabletop exercises: How can you use them to prepare for water system incidents? American Water Works Association Journal, 97(8), 52-57.

[10] Watkins, S. (2000). Developing statewide emergency and disaster preparedness expertise. Journal of the American Institute for Conservation, 39(1), 165-172.

[11] Richter, J., et al. (Nov. 2005). Coastal terrorism: Using tabletop discussions to enhance coastal community infrastructure through relationship building. Journal of Public Health Management, S45-S49.

[12] Graham, B. T. (2011). Bio-defense Report Card - 21st Century Biological Threats. Washington: WMD Center.

[13] Barry, J. (2005). The Great Influenza: the epic story of the deadliest plague in history. New York: Penguin Books.

[14] Florida Department of Health. (2006). 2006 Bioshield Exercise After Action Report. Tallahassee: Florida Department of Health.

[15] Florida Department of Health. (2005). Mass Vaccination Exercise After Action Report. Tallahassee: Florida Department of Health.

[16] Diprose, R. S. (2008, March 20). Governing the Future: The Paradigm of Prudence in Political Technologies of Risk Management. Security Dialogue, 267-288.

[17] Ewald, François, 2002. “The Return of Descartes' Malicious Demon”: An Outline of a Philosophy of Precaution', trans. Stephen Utz, in Tom Baker and Jonathan Simon, eds, Embracing Risk: The Changing Culture of Insurance and Responsibility. Chicago, IL: University of Chicago Press (273-301).

[18] Derrida, Jacques, 2003. 'Autoimmunity: Real and Symbolic Suicides', in Giovanna Borradori, ed., Philosophy in a Time of Terror: Dialogues with Jürgen Habermas and Jacques Derrida. Chicago, IL: University of Chicago Press (85-136).

[19] Samimian-Darash, L. (2011). Governing through time: preparing for future threats to health and security. Sociology of health and illness, 33(6), 930945.

[20] Federal Emergency Management Agency (FEMA). Plan for a Pandemic. (2013). Retrieved April 10, 2013, from: http://www.ready.gov/pandemic 